\title{
UPAYA PENINGKATAN DIPLOMASI PUBLIK INDONESIA DI \\ NEGARA-NEGARA ASEAN MELALUI BEASISWA SENI \\ DAN BUDAYA INDONESIA (BSBI)
}

Dina, Sumiati

Fakultas Ilmu Sosial dan Ilmu Politik Universitas Al-Ghifari Bandung

Jalan A.H. Nasution No.KM.8, Karang Pamulang, Bandung, Kota Bandung, Jwa Barat 40293

E-mail : dina.shusein@gmail.com, Angelmamah01@gmail.com

\begin{abstract}
This paper analyzes how Indonesian Art and Culture Scholarship (IACS) becomes an instrument to improve Indonesian public diplomacy in ASEAN. The Ministry of Foreign Affairs of the Republic of Indonesia has organized the IACS program since 2003. Starting from the ASEAN Community's ratification program in 2015, Indonesia must adjust its public diplomacy in ASEAN region. This paper applies concept of public diplomacy to look at various efforts to improve Indonesian public diplomacy in ASEAN and national interest to analyze why Indonesia uses public diplomacy in achieving Indonesia's national interests. By organizing the IACS program, Indonesia has purpose to introducing Indonesian art and culture to the people of ASEAN countries so that it can improve its public diplomacy and encounter new challenges from the ASEAN Community.
\end{abstract}

Keywords: ASEAN Community, Indonesian Arts and Cultural Scholarship, Ministry of Foreign Affairs of the Republic of Indonesia.

\section{Pendahuluan}

Program Beasiswa Seni dan Budaya Indonesia (BSBI) merupakan program yang dicanangkan oleh Kementrian Luar Negeri Indonesia. Program ini telah dimulai sejak tahun 2003 dan bertujuan untuk menciptakan pemahaman yang lebih baik tentang keberagaman budaya Indonesia. Dalam jangka panjang, program BSBI merupakan sarana kerja sama dalam bidang budaya dan diplomasi antar negara peserta . Program BSBI ini memiliki acara puncak untuk menampilkan apa saja yang telah para peserta pelajari selama mengikuti program BSBI yaitu Indonesia Channel, dan acara ini sekaligus merupakan pertanda berakhirnya program ini.pembelajaran yang ada di Indonesia dan kembali ke negara asal mereka, kementrian luar negeri berharap agar mereka dapat menyampaikan apa saja yang telah dipelajari selama 
program BSBI ini berlangsung ke negara mereka masing-masing. Ini merupakan langkah Indonesia untuk berdiplomasi publik dan termasuk untuk mencapai kepentingan nasionalnya melalui orang-orang yang menerima beasiswa ini di kawasan ASEAN.

Melalui program beasiswa seni dan budaya, Indonesia mulai dapat menggencarkan tentang budaya-budaya yang ada di Indonesia. Hal ini dapat dilihat dari meningkatnya para peserta yang mengikuti program ini. Dari sejak dimulainya pada tahun 2003 hingga 2016, sudah 718 alumni yang berasal dari 63 negara termasuk ASEAN yang mendapatkan beasiswa ini Memang program ini tidaklah mutlak menjadi penyebab kenaikan wisatawan di Indonesia, namun peningkatan ini dapat mengindikasikan sebagai pencapaian awal tujuan dari program tersebut (Warsito \& Kartikasari, 2007: 202). Program ini memang dirancang untuk meningkatkan diplomasi publik Indonesia khususnya melalui pendekatan seni dan budaya. Dalam hal ini Indonesia mencoba menggunakan seni dan budaya sebagai alat diplomasi guna meningkatkan people to people contact yang merupakan salah satu cara penting dalam mendukung keberhasilan diplomasi Indonesia sesuai dengan konsep diplomasi total yang mampu meningkatkan saling pengertian antar bangsa di kawasan ASEAN. Politik luar negeri Indonesia selama ini telah menekankan keberadaan dan partisipasi Indonesia di Association of Southeast Asian Nations atau yang sering disebut dengan ASEAN sebagai salah satu pilar utama orientasi kebijakan luar negeri.

Terlebih lagi dengan dimulainya ASEAN Community atau Masyarakat ASEAN pada tahun 2015 yang mengharuskan Indonesia untuk menyesuaikan diplomasi publiknya di kawasan tersebut. Dengan menyelenggarakan program beasiswa seni dan budaya, Indonesia memiliki tujuan untuk mengenalkan dan mengajarkan seni dan budaya Indonesia kepada masyarakat internasional khususnya negara-negara yang tergabung dalam ASEAN (Warsito \& Kartikasari, 2008: 200). Oleh karena itu program BSBI ini menjadi alat baru bagi diplomasi Indonesia dalam bidang 31 kebudayaan dalam rangka meraih kepentingan nasional Indonesia dalam menghadapi tantangan munculnya Masyarakat ASEAN.

\section{Pembahasan}

Diplomasi Publik dan Kepentingan Nasional Indonesia. Diplomasi secara konseptual dipahami sebagai teknik pelaksanaan kekuasaan untuk mencapai kepentingan di luar negeri (Emilia, 2013: 5). Diplomasi publik merupakan bagian dari aktivitas politik internasional suatu negara merupakan salahsatu aspek penting bagi keberhasilan lobi politik internasional pemerintah atau negara Indonesia. Memenangkan hati dunia terhadap Indonesia tidak dapat 
hanya dicapai dengan diplomasi yang bersifat kaku, namun harus dengan diplomasi yang bergerak fleksibel dan bersahabat. Prinsip "bebas dan aktif" adalah landasan utama yang dijadikan pedoman politik luar negeri Indonesia. Dalam konteks Indonesia, diplomasi publik sedikit berbeda dengan praktek yang banyak dilakukan oleh negara-negara lain khususnya negara maju.

Indonesia melaksanakan diplomasi publik tidak hanya kepada publik internasional tetapi juga kepada publik domestik. Praktek ini dipengaruhi oleh faktor bahwa politik internasional banyak dipengaruhi oleh faktor-faktor internal sebuah negara dan di sisi lain, dinamika politik dalam negeri juga banyak dipengaruhi oleh berbagai isuisu internasional. Untuk itulah diperlukan sebuah mekanisme yang bisa menjembatani dinamika luar negeri untuk kemajuan dalam negeri. Dengan demikian, publik dalam negeri diharapkan dapat semakin mengerti berbagai masalah internasional khususnya isu-isu yang melewati batasbatas negara di dalam dunia internasional yang semakin terbuka. Diplomasi publik juga bertindak sebagai alat untuk menenangkan konflikkonflik yang ada. Dengan dilaksanakannya praktek diplomasi publik ini, Indonesia melalui Kementerian Luar Negeri, diharapkan akan muncul sebuah pemahaman komprehensif mengenai berbagai isu-isu internasional sehingga publik akan dapat memahami langkah-langkah kebijakan luar negeri yang dipilih oleh pemerintah. Tujuan ideal yang hendak dicapai pada nantinya adalah lahirnya kemitraan antara negara/pemerintah dan non-state actor yang berkepentingan. Miroslav Nincic menjelaskan tiga kriteria dalam mendefinisikan kepentingan nasional (Jemadu, 2008: 67).

Pertama, kepentingan itu harus bersifat vital sehingga pencapaiannya menjadi prioritas utama pemerintah dan masyarakat. Kepentingan pelaksanaan program BSBI ini bersifat vital karena melibatkan pemerintah sekaligus masyarakat, para peserta BSBI mengikuti kegiatan dari pemerintah dan masyarakat, seperti contohnya mereka yang mengikuti norma dan adat istiadat di tempat masyarakat yang mereka tinggali, tentu saja dalam hal ini BSBI melibatkan peran pemerintah maupun masyarakat. Kedua, kepentingan nasional harus berkaitan dengan lingkungan internasional. Program ini juga tentu saja berkaitan dengan lingkungan internasional karena para pesertanya berasal dari mancanegara. Ketiga, kepentingan nasional harus melampaui kepentingan yang bersifat partikularistik dari individu, kelompok, atau lembaga pemerintahan sehingga menjadi kepedulian masyarakat keseluruhan. Program ini juga menjadi kepedulian dengan masyarakat Indonesia yang turun langsung terlibat dengan para peserta BSBI, karena kehadiran merek selalu ditunggu-tunggu 
oleh masyarakat Indonesia. Sementara itu, kepentingan nasional dapat bersifat vital dan nonvital (Jemadu, 2008: 68).

Kepentingan nasional bersifat vital atau strategis ketika kepentingan tersebut dalam pencapaiannya menjadi prioritas utama sebuah negara. Kepentingan nasional yang bersifat vital atau strategis suatu negara menjadi taruhan dalam interaksinya dengan aktor lain, misalnya berkaitan dengan isu kedaulatan negara dan keutuhan suatu negara yang menjadi identitas dari kebijakan luar negerinya. Sifat kepentingan ini menyebabkan negara menggunakan segala instrumen yang dimilikinya ---termasuk kekuatan militer--- untuk mempertahankan kedaulatan atau keutuhannya. Selanjutnya, kepentingan nasional bersifat non-vital atau sekunder tidak berhubungan secara langsung dengan eksistensi negara itu tetapi tetap diperjuangkan melalui kebijakan luar negeri, non-vital sekunder. Dalam pencapaiannya juga merupakan prioritas, namun tidak semata mata menjadi yang utama dan dapat menjadi pendukung dari kepentingan vital. Contoh dari kepentingan yang non-vital adalah dalam sektor pariwisata, pertukaran pelajar, pertukaran misi kebudayaan, olah raga dan lain sebagainya.

Dalam studi ini, program BSBI dikategorikan sebagai kepentingan nasional non-vital. BSBI mempunyai peran yang penting dalam diplomasi publik pada umumnya dan khususnya di ASEAN, namun BSBI tidak menjadi cara yang sangat diunggulkan untuk mencapai kepentingan Indonesia di ASEAN. Selain program BSBI, pemerintah Indonesia telah mengambil berbagai bentuk inisiatif diplomasi publik untuk mencapai kepentingan nasional Indonesia di ASEAN. Berbagai bentuk diplomasi publik itu, seperti Bali Democracy Forum (BDF), Bali Democracy Student Conference (BDSC), Diplomacy Festival (DiploFest), forumforum interfaith dialogue baik di dalam maupun di luar negeri. Melalui peningkatan aktivitas diplomasi publik, pemerintah berharap agar upaya diplomasi publik akan berjalan lebih efektif dan memberikan dampak yang lebih luas dan besar kepada masyarakat internasional. Pemerintah juga berharap bahwa keterlibatan publik ini dapat memberikan masukan dan cara pandang yang berbeda dalam memandang suatu masalah.

Tujuan yang lain dari diplomasi publik adalah untuk mengurangi atau menyelesaikan konflik melalui pemahaman komunikasi dan saling mempererat hubungan antar aktor internasional, mempengaruhi pola pikir pemerintah dan mengurangi kesalahan persepsi antara aktor yang terlibat. Pada intinya publik memegang peranan penting dalam menjalankan misi diplomasi sebuah negara, terlebih lagi dalam situasi negara yang telah 
terintegrasi secara beragam dengan berbagai bidang yang variatif. Bagaimanapun juga diplomasi tidak akan berjalan lancar tanpa campur tangan dari publik, oleh karena itu pada sekarang ini setiap negara semakin berlomba-lomba dalam menjalankandiplomasi total atau multi-track diplomacy dengan meningkatkan peranan publik dalam aktivitas diplomasinya untuk tercapainya kesuksesan politik luar negeri.

Beasiswa Seni dan Budaya Indonesia Pada awal dibentuknya program BSBI ini, pemerintah hanya memberikan kepada mahasiswa dari negara yang tergabung dalam anggota forum Southwest Pasific Dialogue (SwPD) yaitu Australia, Filipina, Indonesia, Papua Nugini, Selandia Baru, dan Timor Leste. Pada tahun berikutnya, pemerintah Indonesia menambah negara-negara yang tergabung dalam ASEAN, ASEAN+3 (Cina, Jepang, Korea), dan negara yang tergabung kedalam Pasific Island Forum (PIF) sebagai peserta BSBI. Karena pemerintah Indonesia ingin mengembangkan diplomasi publiknya ke negara-negara tetangga lainnya, hal ini dilakukan agar memudahkan Indonesia untuk memperoleh hubungan kerjasama dengan negara tetangga. Program ini berfungsi untuk menunjukkan komitmen Indonesia sebagai inisiator pembentukan SwPD dan sebagai salah satu negara pendiri ASEAN dalam memajukan kerja sama sosial budaya di kawasan ini. Program ini juga memiliki tujuan untuk mendorong pemahaman yang lebih baik di antara para peserta dari negara-negara anggota melalui seni dan warisan budaya yang sangat beragam di Indonesia. Yang pada akhirnya program ini bertujuan untuk menumbuhkan budaya kerja sama, yang muncul dari kontak langsung dan berbagi budaya di antara orangorang yang terlibat dalam program, yang mengarah ke hubungan diplomatik yang berkembang di wilayah ini dan di seluruh dunia.

Dari pertama di bentuknya program BSBI pada tahun 2003 sampai tahun 2016, program ini telah menghasilkan alumni sebanyak 718 alumni yang berasal dari 63 negara; sampai tahun 2018 telah menghasilkan alumni sebanyak 848 siswa yang berasal dari 69 negara. diakses 9 Februari 2018). Melalui program ini, Pemerintah Indonesia tidak hanya ingin mengenalkan diplomasi publiknya kepada masyarakat Internasional, namun kepada masyarakat Indonesia juga. Hal ini terbukti dengan adanya peserta yang berasal dari Indonesia. Ini dilakukan agar masyarakat Indonesia juga berperan dalam mendukung pemerintah untuk lebih memerankan kegiatan diplomasi secara people to people contact. Pada awal pembentukannya, program BSBI hanya memiliki satu program, yaitu program reguler. Pada tahun 2010, program BSBI diperluas dengan memberikan program kekhususan yang diperuntukkan kepada peserta yang memiliki pengetahuan lebih tentang Indonesia dan 
telah mengikuti studi Indonesia di negara asalnya (http://www.tabloiddiplomasi.org/index.php/2017/10/11/beasiswa-seni-dan-budayaindonesia-dbalik-misi-pencapaian-diplomasi/, diakses 3506 Maret 2018).

Pada program reguler, para peserta penerima beasiswa hanya diajarkan tarian dan budaya dari suatu daerah di sanggar tempat mereka berlatih. Sedangkan pada program kekhususan, tidak hanya soal budaya dan tarian, merek juga belajar tentang bagaimana sejarah, adat, maupun situasi politik yang ada di Indonesia. Dengan adanya program yang mengajarkan tentang politik yang ada di Indonesia, Indonesia juga mempersiapkan dirinya dalam menghadapi tantangan dari adanya Masyarakat ASEAN yaitu tantangan politik keamanan yang merupakan salah satu pilarnya. Setiap sanggar memberi pelatihan tentang budaya yang berbeda menurut daerahnya masing-masing (lihat tabel 1). Hal ini dimaksudkan untuk menambah wawasan bagi para peserta bahwa ada beraneka ragam bentuk kesenian dan Tabel 1. Sanggar bagi Peserta BSBI Sampai 2016.

\begin{tabular}{|l|l|l|l|}
\hline No & Nama Sanggar & Kota & Tahun \\
\hline 1 & Saung Angklung Udjo & Bandung & 2015 \\
\hline 2 & Soeryo Soemirat & Solo & 2015 \\
\hline 3 & Studio Tydif & Surabaya & 2016 \\
\hline 4 & Sanggar Semarandana & Bali & 2016 \\
\hline 5 & Rumah Budaya Rumata & Makassar & 2016 \\
\hline 6 & UPN "Veteran " Yogyakarta & Yogyakarta & 2016 \\
\hline 7 & Sanggar Sofiyani & Padang & 2016 \\
\hline
\end{tabular}

Sumber: diolah dari Tabloid Diplomasi edisi Juni 2015 dan Agustus 2016.

kebudayaan yang dimiliki Indonesia. Contohnya, melalui Jurusan Ilmu Hubungan Internasional, UPN "Veteran" Yogyakarta, para peserta penerima BSBI diajarkan tentang kesenian lokal di Yogyakarta dan juga gamelan Yogyakarta. Selain itu, para peserta yang dikirim ke Yogyakarta juga belajar tentang politik maupun kebijakan, Pada 2017, sanggar bagi pelatihan BSBI terletak di Padang, Suabaya, Denpasar, Makassar, dan Yogyakarta. luar negeri Indonesia. Lain halnya seperti di sanggar Semarandana Bali yang merupakan salah satu sanggar dari program reguler, di sanggar reguler ini mereka tidak diajarkan tentang politik Indonesia. Pemberian pelajaran Bahasa Indonesia juga tidak intensif, seperti pada spesial program di Yogyakarta. Dengan dimulainya ASEAN Community atau Masyarakat ASEAN pada tahun 2015, pemerintah Indonesia ---khususnya Direktorat Diplomasi Publik di 
Kementerian Luar Negeri merasa perlu melalakuan inisiatif diplomasi publiknya bagi kawasan ini.

Melalui program BSBI 2015, Indonesia memiliki tujuan untuk mengenalkan dan mengajarkan seni dan budaya Indonesia kepada masyarakat internasional, khususnnya negara-negara yang tergabung dalam ASEAN (Warsito \& Kartikasari, 2007: 200). Oleh karena itu, program BSBI ini menjadi alat baru bagi diplomasi Indonesia dalam bidang kebudayaan dalam rangka meraih kepentingan nasional Indonesia dalam menghadapi tantangan munculnya Masyarakat ASEAN. Hubungan Indonesia dengan ASEAN ASEAN telah mengalami perkembangan dari masa ke masa sesuai dengan cita-cita para pendiri ASEAN untuk menjalin persahabatan dan kerja sama dalam menciptakan wilayah yang aman, damai dan makmur. Sebagai salah satu pendiri ASEAN, peran serta Indonesia sangatlah penting bagi kawasan tersebut. Indonesia juga beberapa kali menjadi ketua ASEAN di tahun 1976, 2003 dan juga pada tahun 2011. Setelah menjadi ketua ASEAN pada tahun 2011, Indonesia telah memberi bobot pada organisasi kawasan negara-negara di Asia Tenggara. Hal ini terkait dalam upaya memastikan kesiapan negara-negara anggota bagi terwujudnya Komunitas ASEAN 2015.

Menurut Presiden Susilo Bambang Yudhoyono (SBY), Indonesia telah aktif mendorong pelibatan masyarakat dalam kegiatan-kegiatan ASEAN serta peningkatan people to people contact di antara masyarakat negaranegara anggota ASEAN. Semenjak perencanaan Masyarakat ASEAN, Indonesia sudah mulai berperan aktif dalam menghadapi tantangan ketiga pilarnya, khususnya adalah pilar ASCC. Melalui peran aktif dari Indonesia, kemudian menuangkan tekadnya kedalam deklarasi mengenai Persatuan ASEAN dalam Keberagaman Kebudayaan: Menuju Penguatan Komunitas ASEAN (Declarations on ASEAN Unity in Cultural Diversiy: Towards Strengthening ASEAN Communiy) yang ditandatangani para Menteri Kebudayaan negara anggota ASEAN di KTT ke 19 ASEAN 2011.

Dengan adanya ASEAN, Indonesia semakin bisa mengenalkan budaya budayanya yang sangat beragam kepada negara negara tetangga melalui diplomasi publiknya. Selain itu, Indonesia memiliki kepentingan yang tinggi untuk memastikan ASEAN menjadi organisasi yang kuat secara internal, dan dipertimbangkan secara serius oleh dunia internasional. Dengan adanya ASEAN, Indonesia dapat mengenalkan BSBI dengan mudah. Melalui BSBI, Indonesia dapat mendukung kestabilan di wilayah ASEAN karena BSBI ini merupakan beasiswa seni dan budaya pertama yang diadakan oleh Indonesia. BSBI juga mampu 
meningkatkan kunjungan pariwisata yang ada ke Indonesia dari negara-negara yang tergabung dalam, sehingga akan mempermudah Indonesia dalam mencapai kepentingan nasionalnya. Dalam menghadapi Masyarakat ASEAN, Indonesia semakin menggencargencarkan diplomasi publiknya melalui program dari Kementerian Luar Negeri yaitu BSBI. Melalui program BSBI Indonesia ingin menunjukan kepada ASEAN tentang budaya-budaya yang dimiliki Indonesia dengan memberikan kuota penerima BSBI lebih kepada negara negara di ASEAN.

Dari tabel di bawah ini dapat dilihat bahwa meskipun terdapat penurunan jumlah peserta di ASEAN pada tahun 2013 dari tahun 2012, namun pada tahun 2014 ke 2015 terdapat peningkatan yang signifikan dari 15 peserta negara ASEAN menjadi 24 peserta dari negara ASEAN (lihat table 2).

Tabel 2. Jumlah Peserta BSBI ASEAN Tahun 2011-2016.

\begin{tabular}{|l|l|l|l|}
\hline No & Negara & Tahun & Jumlah Peserta \\
\hline 1 & Brunei Darussalam & $2011 / 2012 / 2013 / 2014 / 2015 / 2016$ & $1 /-/-/-/ 1 / 2$ \\
\hline 2 & Filipina & $2011 / 2012 / 2013 / 2014 / 2015 / 2016$ & $1 / 2 / 2 / 2 / 3 / 2$ \\
\hline 3 & Indonesa & $2011 / 2012 / 2013 / 2014 / 2015 / 2016$ & $5 / 7 / 5 / 5 / 6 / 4$ \\
\hline 4 & Kamboja & $2011 / 2012 / 2013 / 2014 / 2015 / 2016$ & $1 / 1 /-/ 1 / 2 / 1$ \\
\hline 5 & Laos & $2011 / 2012 / 2013 / 2014 / 2015 / 2016$ & $1 / 2 / 1 / 1 / 1 / 2$ \\
\hline 6 & Malaysia & $2011 / 2012 / 2013 / 2014 / 2015 / 2016$ & $1 / 1 /-/-/ 2 / 1$ \\
\hline 7 & Myanmar & $2011 / 2012 / 2013 / 2014 / 2015 / 2016$ & $1 / 2 / 2 / 1 / 1 / 1$ \\
\hline 8 & Singapura & $2011 / 2012 / 2013 / 2014 / 2015 / 2016$ & $-/ 1 / 1 /-/-/-$ \\
\hline 9 & Thailand & $2011 / 2012 / 2013 / 2014 / 2015 / 2016$ & $1 / 3 / 2 / 3 / 4 / 3$ \\
\hline 10 & Vietnam & $2011 / 2012 / 2013 / 2014 / 2015 / 2016$ & $1 / 2 / 2 / 2 / 4 / 4$ \\
\hline
\end{tabular}

Sumber diolah dari data Rekapitulasi Peserta milik Kementerian Luar Negeri.

Dapat dilihat bahwa peningkatan jumlah peserta dari ASEAN ini menunjukkan Indonesia benar-benar mempersiapkan negaranya melalui Kementerian Luar Negeri untuk menghadapi tantangan dari terbentuknya Masyarakat ASEAN pada tahun 2015 melalui pengenalan budaya ke perwakilan negara-negara anggota ASEAN. Peningkatan peserta dari ASEAN itu tampak menonjol jika dibandingkan dengan peserta lain dari kawasan Eropa (lihat tabel 3). Sebelum 2015, kawasan Eropa cenderung memiliki lebih banyak kuota peserta yang diterima dibandingkan dengan ASEAN maupun ASEAN+3. Hal ini dikarenakan jumlah negara di kawasa Eropa lebih banyak dibandingkan dengan kawasan ASEAN maupun ASEAN+3, dan juga Eropa menjadi sasaran untuk pengenalan budaya Indonesia melalui BSBI sehingga lebih banyak yang akan berdatangan. Negara-negara yang terletak di bagian Pasifik juga memiliki jumlah peserta yang cenderung stabil, karena program ini memang pada awalnya ditujukan kepada mereka. 
Program BSBI Bertema ASEAN Peran aktif diplomasi publik ditujukan untuk memproyeksikan kepentingan nasional melalui berbagai inisiatif mengkomunikasikan perkembanganinternasional dengan masyarakat di sebuah negara. Dengan demikian, diplomasi harus mampu mendekatkan jarak antara faktor-faktor internasional dan domestik, serta mampu menjadi ujung tombak yang memperjuangkan kepentingan nasional, dan sekaligus mengkomunikasikan perkembangan dalam negeri kepada masyarakat internasional. Program BSBI dari Kementerian Luar Negeri yang ditujukan kepada para masyarakat Internasional sejak tahun 2003 ini merupakan langkah yang bagus untuk menunjang peningkatan diplomasi khususnya diplomasi publik bagi Indonesia. Disatu sisi, pemerintah Indonesia dapat lebih mengenalkan pluralism budaya dan multikulturalisme masyarakat Indonesia kepada masyarakat internasional. Masyakarat Indonesia, khususnya di sekitar sanggar-sanggar pelatihan seni dan budaya, dapat berinteraksi langsung, bertukar pengalaman, dan menjalin jejaring persahabatan lintas-negara dengan peserta internasional, termasuk peserta dari ASEAN pada BSBI 2015.

Di sisi lain, program BSBI juga memberikan kesempatan kepada masyarakat internasional, termasuk peserta dari negara-negara anggota ASEAN, untuk belajar dan mengenal langsung berbagai budaya local di Indonesia. Dengan memberikan BSBI kepada negara-negara lain maupun negara tetangga yang tergabung kedalam kawasan ASEAN, Indonesia dapat memperkuat hubungan kerjasamanya melalui pengenalan budaya terhadap negara-negara tersebut. Melalui program ini juga Indonesia ingin lebih mengenalkan diplomasi publiknya melalui penerima BSBI kepada negaranya sendiri secara langsung. Setelah selesai menjalani serangkaian program dari BSBI ini, para peserta akan menjadi Friends of Indonesia dan diharapkan dapat menjadi duta Indonesia di negara asalnya. Peningkatan diplomasi publik melalui BSBI ini dilakukan dan diterapkan oleh Kementerian Luar Negeri Republik Indonesia maupun Kedutaankedutaan besar dan konsulat jendral yang ada di luar negeri terutama di wilayah ASEAN melalui program program tentang penyuluhan BSBI maupun menggelar acara-acara reuni yang melibatkan para alumni BSBI untuk saling berbagi pengalaman tentang program tersebut.

Kementerian Luar Negeri Republik Indonesia juga mengadakan penutupan program BSBI yang berupa Indonesia Channel. Disamping sebagai penutup program, Indonesia Channel ini juga berfungsi sebagai upaya bagi peningkatan diplomasi publik bagi Indonesia di ASEAN. Karena dalam acara ini tidak hanya mengundang dari dalam negeri, namun juga duta besar dari negara-negara tetangga turut diundang dalam acara ini. Tujuan dari Indonesia 
Channel dengan mengundang duta besar dari negara tetangga juga untuk mengenalkan dan meyakinkan kepada tiap-tiap perwakilan negara bahwa masyarakat mereka telah terpercaya untuk mengenalkan budaya Indonesia di negara mereka. Upaya yang lain juga dilakukan oleh Kementerian Luar Negeri dengan membuat akun instagram BSBI @iacs_kemlu, akun ini dibuat dengan tujuan untuk membagikan kegiatan kegiatan selama program BSBI berlangsung. Terlebih lagi di zaman sekarang ini media sosial sangat mendukung proses penyebaran informasi, dengan adanya media sosial seperti instagram ini, penyebaran informasi tentang diplomasi publik Indonesia menjadi sangat pesat. Selain untuk meningkatkan diplomasi publik Indonesia, BSBI juga mampu untuk meningkatkan citra negara Indonesia. Mengingat citra negara penting bagi suatu negara, upaya diplomasi publik yang dilakukan oleh Indonesia melalui Kementerian Luar Negerinya maupun melalui peserta BSBI ini dapat mempengaruhi peningkatan citra Indonesia di mata negara-negara lain.

\section{Kesimpulan}

Diplomasi publik menjadi sebuah alat baru bagi setiap negara untuk menenangkan konflikkonflik yang terjadi, tak terkecuali Indonesia. Diplomasi publik yang dilakukan Indonesia sedikit berbeda dengan praktek yang banyak dilakukan oleh negara-negara lain khususnya negara maju. Indonesia melaksanakan diplomasi publik tidak hanya kepada publik internasional tetapi juga kepada publik domestik. Melalui diplomasi publik, tujuan ideal yang hendak dicapai pada nantinya adalah lahirnya kemitraan antara negara/pemerintah dan nonstate actors yang berkepentingan. Peranan diplomasi publik dibutuhkan untuk memberikan citra positif terhadap politik luar negeri negara-negara ASEAN, dalam mengembangkan citra positif ini memerlukan perangkat implementasi diplomasi publik yang tepat pula agar tepat pada sasaran yang diharapkan sebagai solusi mengatasi berbagai perbedaan yang terdapat di negara-negara di ASEAN. BSBI merupakan salah satu cara yang dilakukan Indonesia dalam langkah diplomasi publiknya. 


\section{Daftar Pustaka}

Beasiswa Seni dan Budaya Indonesia 2016 https://www.kemlu.go.id/search/results.

aspx $? \mathrm{k}=$ Search\%2E\%2E\%2Ebsbi\%202016\#k=beasiswa\%20seni\%20dan\%20budaya\%20indonesia\%2 02016, diakses 9 Februari 2018.

beasiswa Seni dan Budaya Indonesia, https://www.kemlu.go.id/id/lembarinformasi/Pages/2017Beasiswa-Seni-dan-Budaya-Indonesia.aspx, diakses06 Maret 2018.

Dirjen Informasi dan Diplomasi Publik Kementerian Luar Negeri RI, 2016, LKJ Ditjen IDP TA 2015, Jakarta.

Emilia, Rani, 2013, Praktek Diplomasi, Jakarta, Baduose Media.

Jemadu, Aleksius. 2008, Politik Global dalam Teori dan Praktik, Graha Ilmu,Bandung.

Pembentukan Masyarakat ASEAN 2015, https://www.kemlu.go.id/id/kebijakan/asean/Pages/Pembentukan-Masyarakat-ASEAN-2015.aspx, diakses 7 Maret 2018.

Peran Indonesia Perkuat ASEAN, https://internasional.kompas.com/read/2011/08/16/13463365/Peran.Indonesia.Perkuat.ASEAN, diakses 23 Juni 2018.

Southwest Pasific Dialogue (SwPD), https://www.kemlu.go.id/id/kebijakan/kerjasamaregional/Pages/SwPD.aspx, diakses 30 Juni 2018.

Warsito, Tulus dan Wahyuni Kartikasari. 2007. Diplomasi Kebudayaan, Konsep dan Relevansi Bagi Negara Berkembang: Studi Kasus Indonesia, Yogyakarta, Ombak.

(https://www.kemlu.go.id/id/lembar-informasi/Pages/2017-Beasiswa-Senidan-BudayaIndonesia.aspx, diakses 06 Maret 2018). 